\title{
Cyclic Behavior of Bolted Extended End-Plate Moment Connections with Different Sizes of End Plate and Bolt Stiffened by a Rib Plate
}

\author{
Abbas Haghollahi ${ }^{a}$, Reza Jannesar ${ }^{a^{*}}$ \\ ${ }^{a}$ Faculty of Civil Engineering, Shahid Rajaee Teacher Training University, Tehran, Iran. \\ Received 08 January 2018; Accepted 03 February 2018
}

\begin{abstract}
This paper presents a numerical study on the behavior of prequalified Bolted Extended End Plate (BEEP) moment connections when are affected by cyclic loading. Specimens were six four-bolt extended end-plate connections consist of $\mathrm{H}$-shaped columns and I-shaped beams with different geometry as well as different end-plate size and bolt diameter; three of them were stiffened by a triangular rib plate welded to the top and bottom of the beam flanges, and others remained unstiffened. They were modeled in ABAQUS software and their cyclic behavior was evaluated using finite element analysis. Responses of specimens were examined by presenting their equivalent plastic strain, stress distribution, and moment-rotation hysteretic curves. Results revealed that with the increase of beam height and inertia moment in equal story drift rotations, the reduction of connection strength occurred earlier due to the occurrence of local buckling in the beam web and flange after subjecting to cyclic loading. By comparing moment-rotation hysteretic responses of specimens, it was found out that in unstiffened BEEP connections with thinner end-plate, the use of single vertical rib stiffener can slightly improve their cyclic behavior, but in connections with thicker end plate, it showed no considerable effect. It was concluded that the BEEP connections whose dimensions are not based on the tenth code of the Iranian national building regulations, cannot satisfy the criteria of AISC seismic provisions for both special and intermediate steel moment frames, although they experienced no local beam web and flange buckling.
\end{abstract}

Keywords: Bolted Extended End-Plate Connection; Unstiffened; Rib Stiffener; Steel Moment Frame; Finite Element Analysis.

\section{Introduction}

Nowadays, the use of bolted extended end-plate (BEEP) moment connections has become popular due to ease of fabrication, erection, and proper seismic performance. These connections are for connecting a beam to column or splicing two beams together. BEEP moment connections are included in the 2010 ANSI/AISC 358 [1], and seismic test results have shown them to be capable of providing considerable ductility and seismic resilience. These connections are prequalified moment connections in the AISC 358 standard [1] for special moment frames (SMFs). BEEP connections are classified in terms of relationship between the moment transmitted by the connection and their rotation in the plane of connection [2]. According to European Standard [3] and many other studies; it can be classified by its rotational stiffness, strength and ductility. There are three types of BEEP connections including four-bolt unstiffened, four-bolt stiffened, and the eight-bolt stiffened. "In stiffened connections, a triangular stiffener is welded between the outer surface of the beam flange and the extended portion of the end plate" [4]. This stiffener increases the strength and stiffness of the end plate, and reduces prying action and distributes flange forces among the bolt group.

The behavior of the prequalified BEEP connections has been investigated through many experimental and analytical studies. The earlier studies have shown that the ductility and energy dissipation of four-bolt unstiffened and stiffened extended end-plate connections can be improved if end plate, end plate stiffener and bolts are designed to

* Corresponding author: rezajannesar.srttu@gmail.com

\section{doi) http://dx.doi.org/10.28991/cej-030979}

$>$ This is an open access article under the CC-BY license (https://creativecommons.org/licenses/by/4.0/).

(C) Authors retain all copyrights. 
experience limited inelastic action, and forcing beam yielding and panel zone deformation to provide the inelastic rotation [5-7]. Ghobarah et al. [6] studied behaviour of this type of connections under cyclic loading to show the effect of design parameters on the overall behaviour. The parameters were: end-plate thickness, column flange stiffener and bolt pre-tension force. They concluded that extended end-plate connection that are properly designed and detailed, can provide excellent ductility. Sumner [8] showed that four-bolt stiffened connections need thinner end plates than four bolt unstiffened connections. According to their results, the four bolts extended unstiffened and the eight bolts extended stiffened end-plate moment connections can be used in seismic regions. Shi et al. [9] presented a new theoretical model for evaluating the moment-rotation relation for stiffened and extended steel beam-column end-plate connection. Mohamadi-Shoore and Mofid [10] developed a new exponential model to predict the standard momentrotation curves of bolted end-plate connections. Abidelah et al. [11] studied experimental and analytical behavior of bolted end-plate connections with or without stiffeners. The results were analyzed on the basis of the global momentrotation curves and the evolution of the tension forces in the bolts.

There are also some numerical studies conducted on the behavior of BEEP connections. Among recent works, Mashaly et al. [12] conducted a parametric study to analyze the effect of 12 material and geometric properties on the behavior of four-bolt extended end-plate connections under lateral loading. They used finite element models in ANSYS software. They found out that the effects of studied parameters depend on the energy dissipation of the connection. Kiamanesh et al. [13] investigated numerically the behavior of extended end-plate connections with a circular bolt pattern under static and cyclic loads. They studied the effects of different bolt diameters and end-plate thicknesses on the bolt-force distribution of each bolt pattern. Their results revealed that the circular bolt pattern can improve the moment capacity. Also, it can reduce pinching, and increase the energy dissipation of the connections which depends on their geometric parameters. Dessouki et al. [14] presented a finite element model to study the nonlinear behavior of the extended end-plate moment connections. Their model had two end-plate configurations: four bolts and multiple row extended end plates. Also, their studied parameters were: beam depth, end-plate thickness, bolts diameter, bolts pitch, bolts gage, and end-plate stiffener. Wang et al. [15], presenting a finite element modeling of the seismic behaviors of extended end-plate connection under cyclic loading, found out that by reliable connection of beam to column, the extended end-plate connection can achieve the same ultimate carrying capacity and initial stiffness as the welded connections, but they had different hysteretic curves, degradation developing curves, and fracture tendency. Ismail et al. [2] studied the effect of different geometrical parameters on the ultimate behavior of BEEP connection with different bolt diameter, end-plate thickness, column stiffener length, and rib stiffener angle by presenting a 3D finite element model. For the extended end-plate with rib stiffener, by the increase of end-plate thickness, the initial stiffness increased significantly, but with the increase of bolt diameter, its initial stiffness increased slightly. Also, it was observed that the bolt diameter and end-plate thickness had significant effect on the ultimate moment and rotation capacity. Morrison et al. [4] studied performance enhancement of eight-bolt stiffened and unstiffened extended end-plate moment connections under simulated seismic loading where the end plate stiffener was removed and the arrangement of bolts was modified in order to enhance uniform distribution of flange forces. The connection was developed using finite element analysis. Despite requiring thicker end plates, the proposed connection reduced costs from the removal of the end plate stiffener.

Most of numerical studies focused on monotonic loading conditions. Most of these reports were not satisfied. The numerical simulation of end-plate connection under cyclic loading is difficult to achieve due to complicated contact relations and high nonlinear behaviors [16]. Also, the responses of steels under cyclic loading and monotonic loading are different [16]. Given these, in this study we investigated non-linear behavior of four-bolt unstiffined extended endplate connections under cyclic loading by presenting a finite element model of connection and analyzing the effect of a triangular rib stiffener on their cyclic behavior. We attempted to examine the applicability of these connections for special and intermediate steel moment frames according to 2005 AISC provisions [17] by presenting moment-rotation hysteric responses of connections.

\section{Research Methodology}

To obtain an efficient and accurate finite element method, the analysis is conducted in ABAQUS software. We carried out the numerical study on an exterior T-shaped joint model and considered it as a subassemblage for connection study. It is assumed that the column is pin-supported at mid-story, and the beam is pin-supported at midspan. The structure was a 10-storey steel moment-resisting frame which was designed according to common design procedure in Iran where bolted unstiffined extended end-plate (BUEEP) model was considered for beam to-column connection. The structure had a 6-m span and a floor height of $3.2 \mathrm{~m}$ with intermediate ductility located in Faruj County, North Khorasan Province, Iran where there is a high relative risk of earthquake. Storey dead and live loads are 600 and $200 \mathrm{Kgf} / \mathrm{m}^{2}$, respectively. Design frame and subassemblage model is shown in Figure 1. Design of connection elements is conducted based on Load and Resistance Factor Design (LRFD) method and Iranian national building regulations. 
Six models of four-bolt extended end-plate connections were designed in this study. Table 1 presents the properties of test specimens. Specimens A200-T, B350-T, and C450-T are stiffened by a single triangular rib plate with a dimension of $125 \times 25 \times 20 \mathrm{~mm}$ welded vertically between the outer surface of the beam flange and the extended portion of the end plate, while specimens A200, B350, and C450 are unstiffened connections. All models consist of welded Hshaped steel columns. Specimens B350 and B350-T consist of welded I-shaped plate girders with a dimension of $350 \times 240 \times 20 \times 12(\mathrm{~mm})$ and others had welded IPE beam sections. Dimensions of beams, columns, end plates and bolts were different for specimens according to the tenth code of the Iranian national building regulations [18] except for A200 and A200-T which did not meet the criteria mentioned in [18]. For these two specimens, bolts diameter are 20 and $22 \mathrm{~mm}$, with a $25 \mathrm{~mm}$ end-plate thickness, a $500 \mathrm{~mm}$ end-plate depth, a $250 \mathrm{~mm}$ end-plate width, H$400 \times 350 \times 25 \times 15$ column section, and IPE200 beam section.

For meshing BEEP connections and its elements, eight-node brick element (C3D8I) was used. Figure 2 presents finite element model of four-bolt stiffened extended end-plate connection. In the vicinity of the connected area, the mesh size is $10 \mathrm{~mm}$ and in the farther areas, it is $50 \mathrm{~mm}$. The boundary conditions are in accordance with typical tests hinged at each end of column by modeling a rigid plate using shell element with six degrees of freedom per node based on Tie constraint.

Bilinear elastic-plastic stress-strain relationship is used to define material properties. The material used for the beam, end plate, and stiffeners uses the curve in Figure 3, while material for high strength bolts uses the curve in Figure 4. We used Q345B steel (a Chinese standardized medium tensile strength steel), and 10.9 level frictional high strength bolts. The material properties of the used steel and bolts with Poisson's ratio of 0.3 are shown in Tables 2 and 3. All the steel components use Von-Mises yield criterion coupled with kinematic hardening rule.

The test specimens were subjected to a cyclic loading according to ATC-24 protocol [19]. When the model is loaded cyclically, it follows the load history as shown in Figure 5. The history contains at least six increasing displacement cycles. It suggests that the increment change in peak deformation between load steps for the specimen should correspond to the deformation at an increase in storey drift equal to the yield displacement of the storey [20]. The cyclic displacement is corresponding to inter-story drift angle which applied to the tip of beam. Before applying, bolts were pre-stressed according to [18].

Moment-rotation hysteretic curves of all specimens were illustrated to investigate the strength of connections. In this regard, the beam moment was measured at the column face versus story drift which is defined as:

$$
M=P \times L_{b}
$$

$$
\theta=\frac{\Delta}{\left(L_{b}+\frac{d_{c}}{2}\right)}
$$

Also, in order to find out the influence of panel zone (PZ) on the cyclic behavior of specimens, moment-PZ rotation hysteretic curves were illustrated. The definition of PZ rotation $\left(\gamma_{\mathrm{PZ}}\right)$ is shown in the equation below, where $a$ and $b$ are initial length and width of panel zone, and $\delta_{1}$ and $\delta_{2}$ show variations in diagonal lengths of panel zone:

$$
\gamma_{P Z}=\frac{\sqrt{a^{2}+b^{2}}}{2 a b}\left(\delta_{1}-\delta_{2}\right)
$$



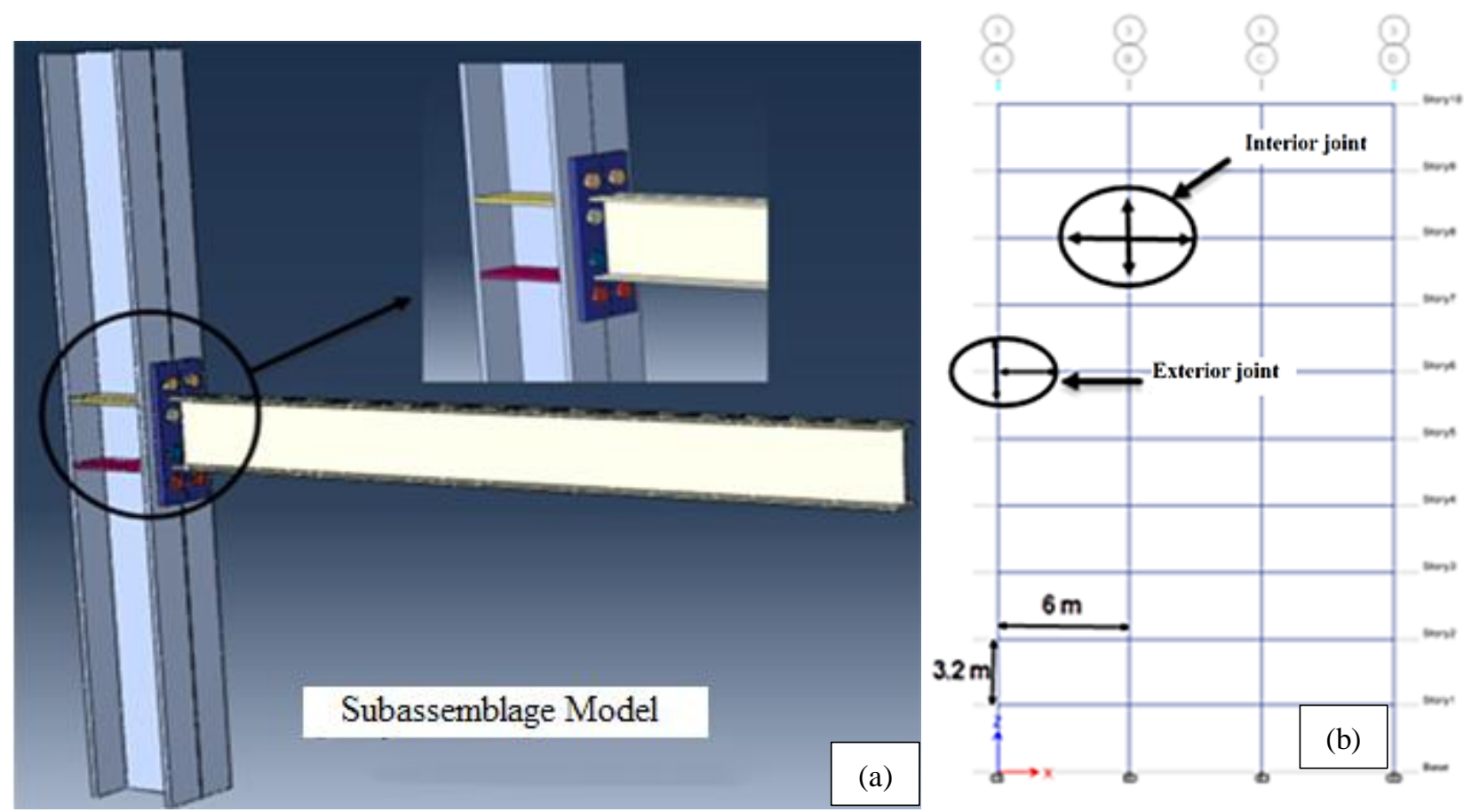

Figure 1. (a) Typical subassemblage model and (b) the plan of designed frame

Table 1. Details of test specimens

\begin{tabular}{|c|c|c|c|c|c|c|c|c|c|c|}
\hline \multirow{2}{*}{ Specimen } & \multirow{2}{*}{ Beam (mm) } & \multirow{2}{*}{ Column (mm) } & \multicolumn{3}{|c|}{$\begin{array}{c}\text { End plate } \\
(\mathbf{m m})\end{array}$} & \multirow{2}{*}{$\begin{array}{c}\begin{array}{c}\text { Bolt } \\
(\mathrm{mm})\end{array} \\
d_{b}\end{array}$} & \multicolumn{3}{|c|}{$\begin{array}{c}\text { Triangular rib stiffener } \\
(\mathbf{m m})\end{array}$} & \multirow{2}{*}{$\begin{array}{l}\text { Prestressing force of bolts } \\
\text { (KN) }\end{array}$} \\
\hline & & & $d_{p}$ & $b_{p}$ & $t_{p}$ & & $l_{s}$ & $b_{s}$ & $t_{s}$ & \\
\hline A200 & IPE200 & $\begin{array}{c}\text { H- } \\
400 \times 350 \times 25 \times 15\end{array}$ & 500 & 250 & 25 & 20 & & - & & 179 \\
\hline A200-T & IPE200 & $\frac{\text { H- }}{400 \times 350 \times 25 \times 15}$ & 500 & 250 & 25 & 22 & 125 & 25 & 20 & 221 \\
\hline B350 & $350 \times 240 \times 20 \times 12$ & $\begin{array}{c}\text { H- } \\
400 \times 350 \times 40 \times 33\end{array}$ & 600 & 250 & 45 & 36 & & - & & 595 \\
\hline B350-T & $350 \times 240 \times 20 \times 12$ & $\begin{array}{c}\text { H- } \\
400 \times 350 \times 40 \times 33\end{array}$ & 600 & 250 & 45 & 36 & 125 & 25 & 20 & 595 \\
\hline $\mathrm{C} 450$ & IPE450 & $\begin{array}{c}\text { H- } \\
400 \times 350 \times 40 \times 33\end{array}$ & 700 & 300 & 35 & 36 & & - & & 595 \\
\hline $\mathrm{C} 450-\mathrm{T}$ & IPE450 & $\begin{array}{c}\mathrm{H}- \\
400 \times 350 \times 40 \times 33\end{array}$ & 700 & 300 & 35 & 36 & 125 & 25 & 20 & 595 \\
\hline
\end{tabular}

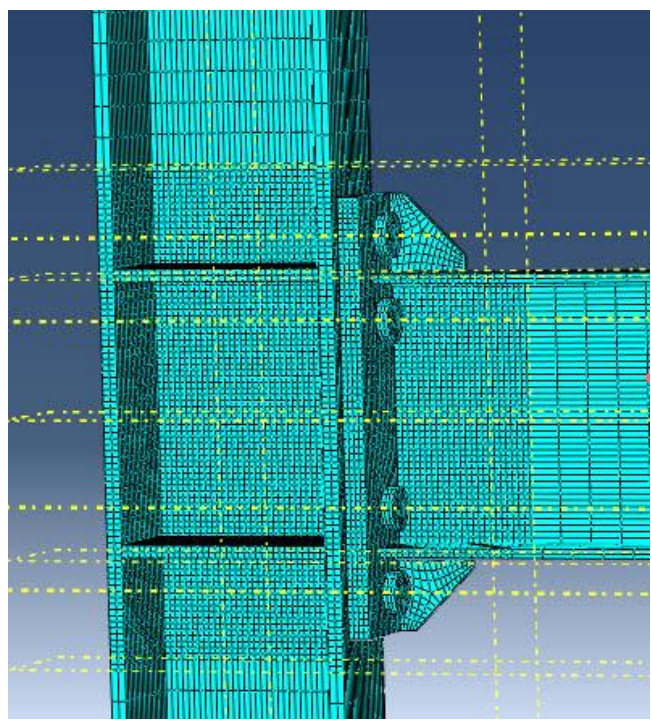

Figure 2. Finite element model of a typical four-bolt stiffened extended end plate connection 
Table 2. Material properties of Q345B steel [15]

\begin{tabular}{cccccccccccc}
\hline Material & $\boldsymbol{\sigma} \mid \mathbf{0}\left(\mathbf{N} / \mathbf{m m}^{2}\right)$ & $\mathbf{Q}_{\infty}\left(\mathbf{N} / \mathbf{m m}^{\mathbf{2}}\right)$ & $\mathbf{b}$ & $\mathbf{C}_{\mathbf{1}}\left(\mathbf{N} / \mathbf{m m}^{\mathbf{2}}\right)$ & $\boldsymbol{\gamma}_{\mathbf{1}}$ & $\mathbf{C 2}\left(\mathbf{N} / \mathbf{m m}^{\mathbf{2}}\right)$ & $\boldsymbol{\gamma}_{\mathbf{2}}$ & $\mathbf{C 3}\left(\mathbf{N} / \mathbf{m m}^{\mathbf{2}}\right)$ & $\boldsymbol{\gamma}_{\mathbf{3}}$ & $\mathbf{C 4}\left(\mathbf{N} / \mathbf{m m}^{\mathbf{2}}\right)$ & $\boldsymbol{\gamma}_{\mathbf{4}}$ \\
\hline $\mathrm{Q} 345 \mathrm{~B}$ & 363.3 & 21 & 1.2 & 7993 & 175 & 6773 & 116 & 2854 & 34 & 1450 & 29 \\
\hline
\end{tabular}

Table 3. Material properties of the used bolts

\begin{tabular}{ccccc}
\hline Material & Modulus of Elasticity & Yield Stress (MPa) & Ultimate Stress (MPa) & Ultimate Stress \\
\hline Bolt 10.9 & 20,000 & 960 & 1000 & 0.138 \\
\hline
\end{tabular}

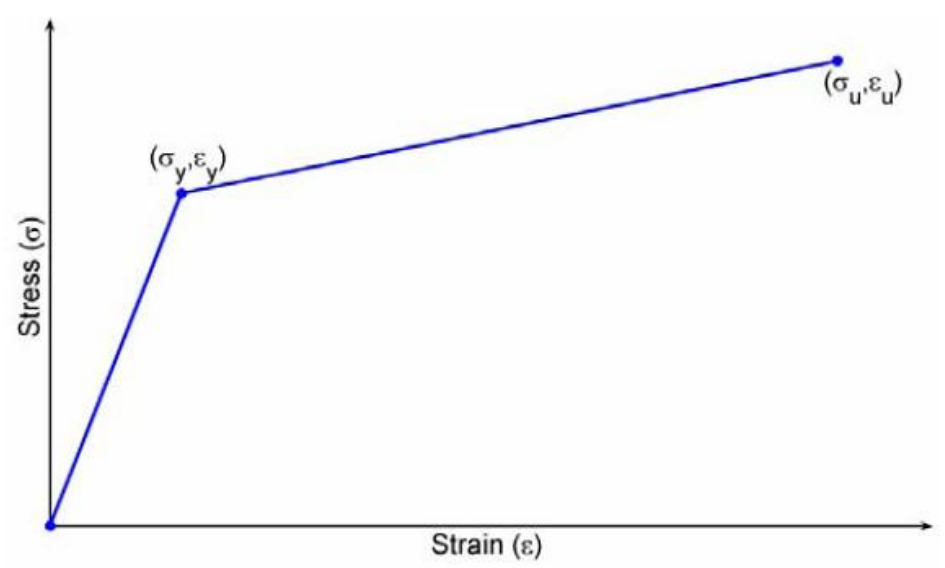

Figure 3. Elastic-plastic stress-strain model of steel beam and column [21]

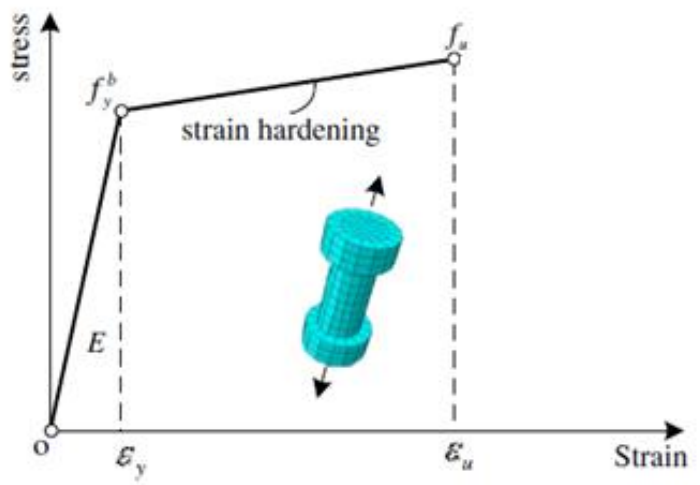

Figure 4. Elastic-plastic stress-strain model of bolts

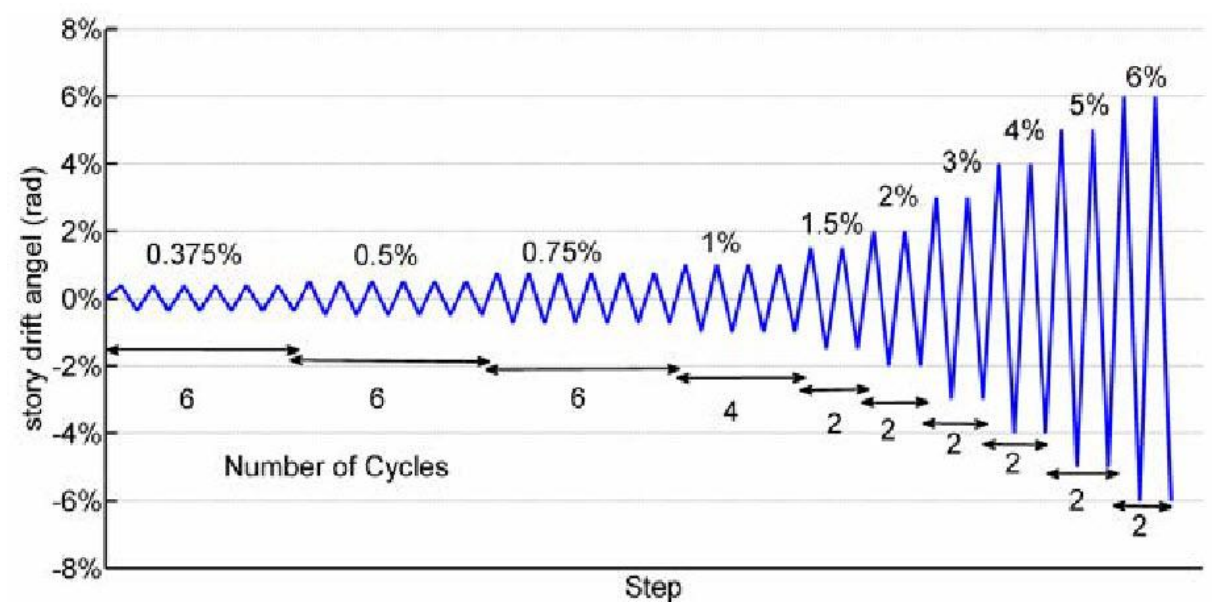

Figure 5. Assumed cyclic loading [21] 


\subsection{Test Verification}

For validating the accuracy and applicability of non-linear finite element model of end plate connection presented in this study, the numerical results were calibrated with the model tested by Shi et al. [22] which is shown in Figure 6. A group of 16 specimens were tested to study the behaviors of end-plate connections consisting of a welded H-shaped beam H-300 $\times 200 \times 8 \times 12 \mathrm{~mm}$ and a welded H-shaped column H-300 $\times 250 \times 8 \times 12 \mathrm{~mm}$. Details of connection can be found in Reference [22]. Eight specimens were subjected to monotonic loadings and other eight specimens were subjected to cyclic loadings. Figure 7 presents the load-displacement curves of numerical results and those of experimental results presented in [22] which indicates a good agreement between them. Hence, finite element models presented in this study are validated (Error rate $=$ less than $5 \%$ ).

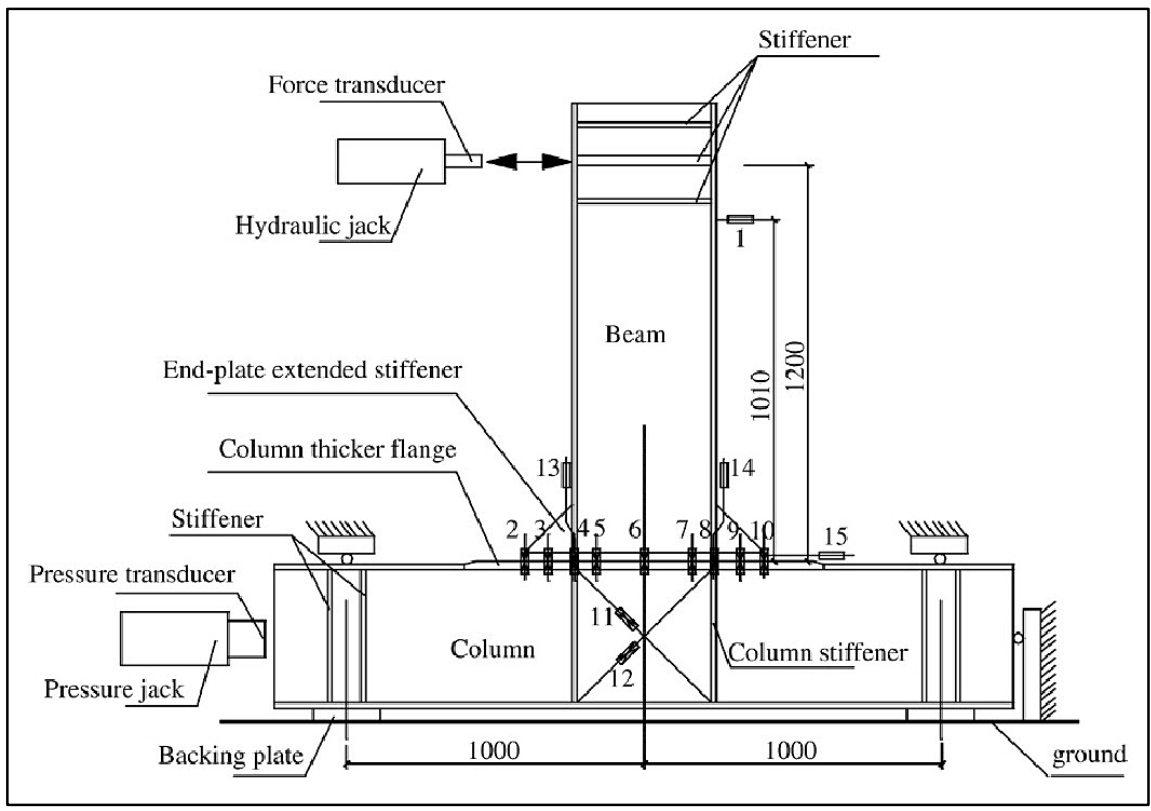

Figure 6. BEEP moment connection model tested in [21]

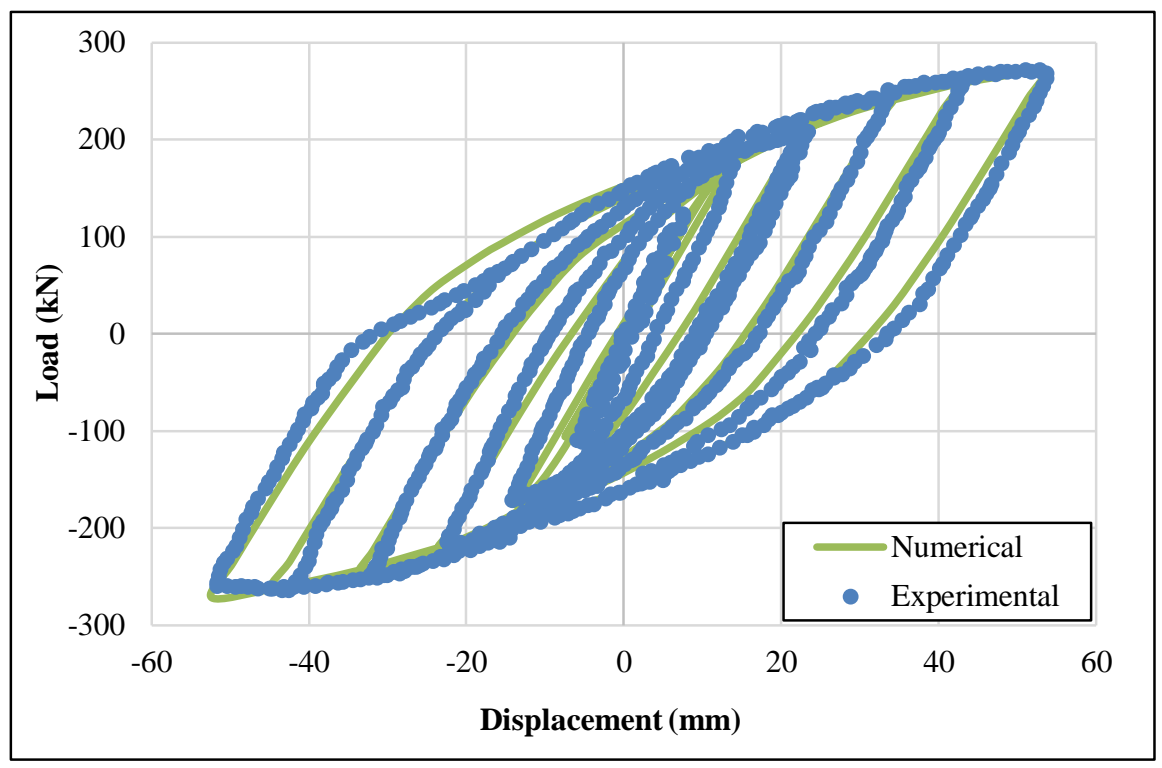

Figure 7. Comparison of numerical and experimental results

\section{Results and Discussion}

\subsection{Equivalent Plastic Strain and Von-Mises Stress Distribution}

Equivalent plastic strain (PEEQ) and von Mises stress distribution at test specimens are shown in Figures 8 and 9. As can be seen, in stiffened specimens, the stress has increased due to the use of rib plate. PEEQ index was employed to measure inelastic strain demands which are defined as the ratio of the equivalent plastic strain to the yield strain. Its results showed that, in unstiffened specimens, the farther we get from the beam-column joint interface, the higher equivalent plastic strain is observed. It was observed that the plastic hinges in unstiffened connections were formed 
near the joint area (with the highest stress distribution), while in stiffened connections they were formed little far from the joint area and after the rib stiffener. PEEQ index for specimen A200-T increased by 85.6\% compared to A200. This increase for specimen B350-T compared to B350 was 55.3\%, and for C450-T compared to C450 was $32.5 \%$. In this basis, we can say that by the use of end-plate rib stiffener and the beams with greater inertia moment, the potential for better plastic hinge formation increases at a location away from the connection area which results in better behavior of stiffened BEEP connections compared to the unstiffened models.
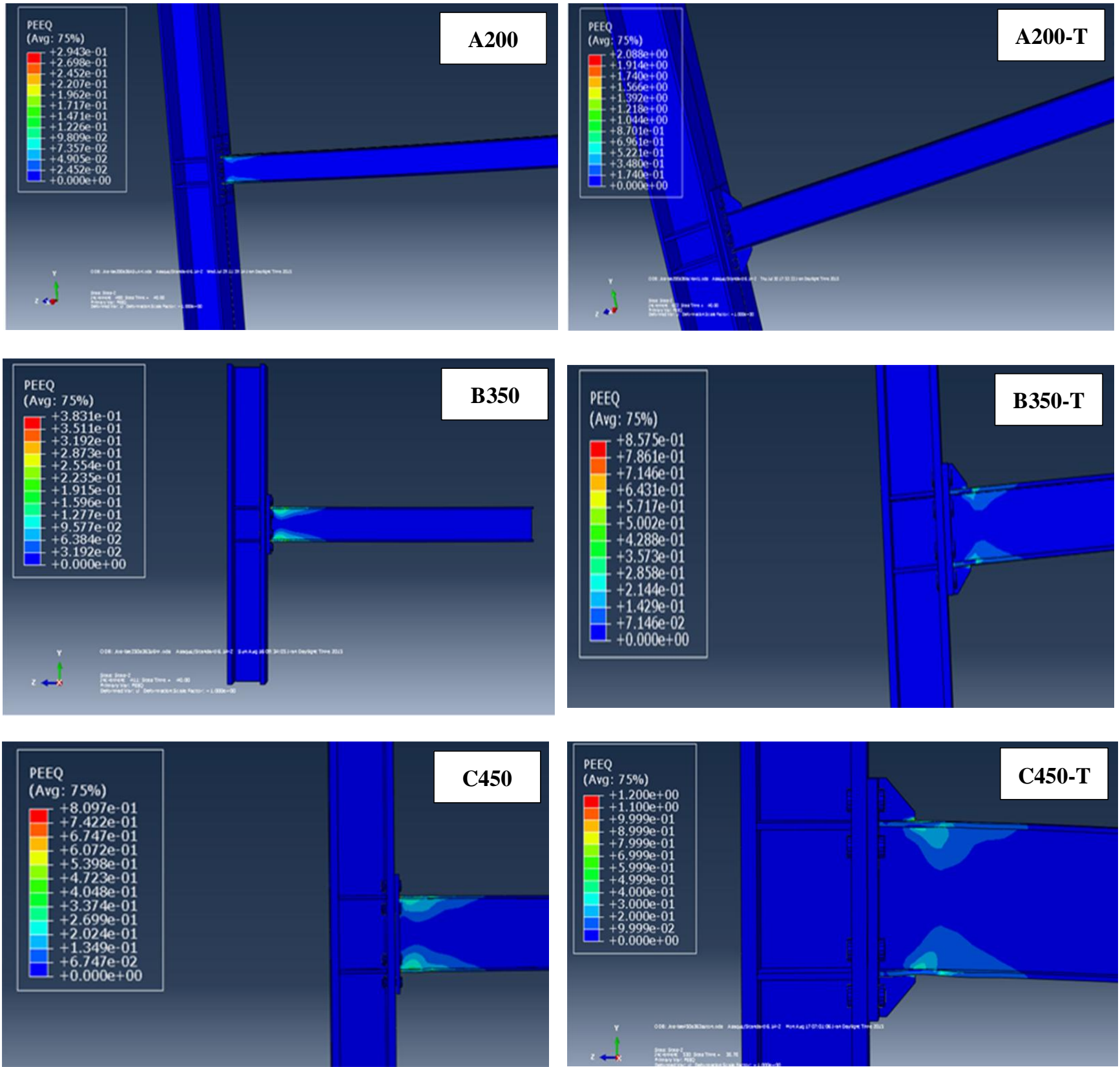

Figure 8. Equivalent plastic strain distributions for 0.06 rad inter story drift 

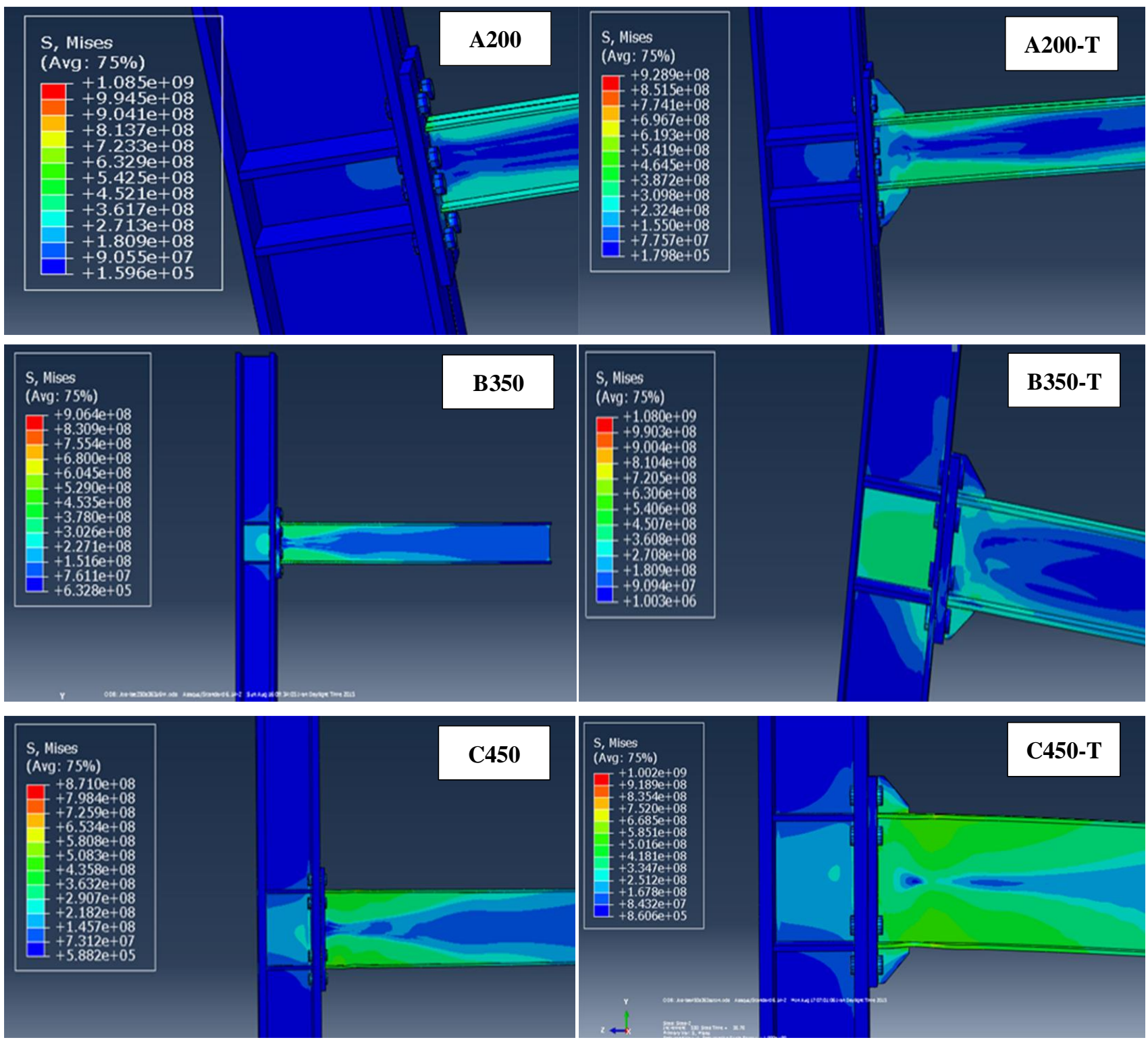

Figure 9. Von-Mises stress distributions for 0.06 rad inter story drift

\subsection{Hysteretic Curves}

Moment-rotation hysteretic curves as well as envelope curves of all specimens resulted from the finite element analysis are presented in Figure 10. According to the results, in specimens A200 and A200-T which had the same end plates $(500 \times 250 \times 25 \mathrm{~mm})$ but with different bolt diameter $(20$ and $22 \mathrm{~mm})$, no local buckling occurred in the beam web and flange; hence, no strength reduction happened. B350 and B350-T with bigger end plates $(600 \times 250 \times 45 \mathrm{~mm})$ and bolt diameter $(36 \mathrm{~mm})$ compared to A200 and A200-T, also experienced no local buckling and no reduction in connection strength, but in specimens C450 and C450-T with end-plate dimension of $700 \times 300 \times 35 \mathrm{~mm}$ and $36-\mathrm{mm}$ bolt diameter, local buckling occurred in the beam flange at $0.036 \mathrm{rad}$ which caused buckling in the web. The web and flange buckling reduced connection strength in these specimens such that the reduction rate at the last loading cycle (0.06 rad) was reported as 6.95 and $3.89 \%$ for specimens C450 and C450-T, respectively. In B350 and B350-T as well as C450 and C450-T, due to the use of thicker end plates compared to specimens A200 and A200-T, there was little change in the resistance and ductility of connections. Moreover, analysis of envelope curves showed that with the increase of the beam height and moment of inertia, the strength and ductility of connections increased. In the beams with more height, strength of connection was reduced earlier than those with lower height which is because of the local buckling occurrence in beam web and flange after subjecting to cyclic loading.

Moment-PZ rotation responses of specimen under finite element analysis are shown in Figure 11. It can be observed that plastic deformation is linear at positive and negative loading cycles. Due to the use of rib stiffener, the strength of the connections increased which reduced rotation at both positive and negative loading cycles. We found out that the 
PZ rotation was negligible, and beams with more symmetrical cross sections and same moment of inertia around the strong and weak axes can show better cyclic behavior.

\subsection{Applicability of Studied BEEP Connections in Special and Intermediate Steel Moment Frames}

According to [17], inelastic rotation capacity of the special moment frames (SMFs) should be at least 0.03 radian story drift, and the flexural capacity of the specimen at the column face should not be less than $80 \%$ of the beam plastic moment $(0.8 \mathrm{Mp})$ at 0.04 radian story drift. For intermediate moment frames (IMFs), inelastic rotation capacity should be up to $0.02 \mathrm{rad}$, and the flexural capacity of the specimen at the column face should not be less than $80 \%$ of the beam plastic moment at 0.02 rad story drift. In this basis, according to the results presented in above section, specimens A200 and A200-T with IPE200 beam sections whose dimensions have not met the criteria of Iranian national building regulations [18], despite having a good strength at $4 \%$ rad (higher than $0.8 \mathrm{Mp}$ ), did not satisfy the acceptance criteria of AISC provisions to have a strength at least $0.8 \mathrm{Mp}$ at 0.02 , and $0.04 \mathrm{rad}$; hence, they did not meet the special and intermediate moment requirements. So we can say that these connections cannot be applied in SMF and IMF systems. In specimens B350 and B350-T made of I-shaped plate girders whose dimensions were according to [18], and have the ability to reach yield stress and complete plasticization of the beam members before local buckling, the moment at the column face was higher than $0.8 \mathrm{Mp}$ at 0.02 and 0.04 radian story drifts. This indicates that these specimens have satisfied AISC provisions' acceptance criteria and hence, they can be employed in SMF and IMFs. Finally, in specimens C450 and C450-T with IPE450 beam sections whose dimensions are based on criteria mentioned in Reference [18], and have the largest beam height, although the moment at the column face was higher than $0.8 \mathrm{Mp}$ at 0.04 radian, but due to the loss of strength at an angle of less than $4 \%$ radian, these connections did not meet the special moment requirements and therefore, they cannot be used in SMFs; however, they met the acceptance criteria of AISC provisions to be used in IMF systems since their moment at the column face were up to $0.8 \mathrm{Mp}$ at $2 \%$ rad, and the connection strength reduction occurred at an angle more than $0.02 \mathrm{rad}$.

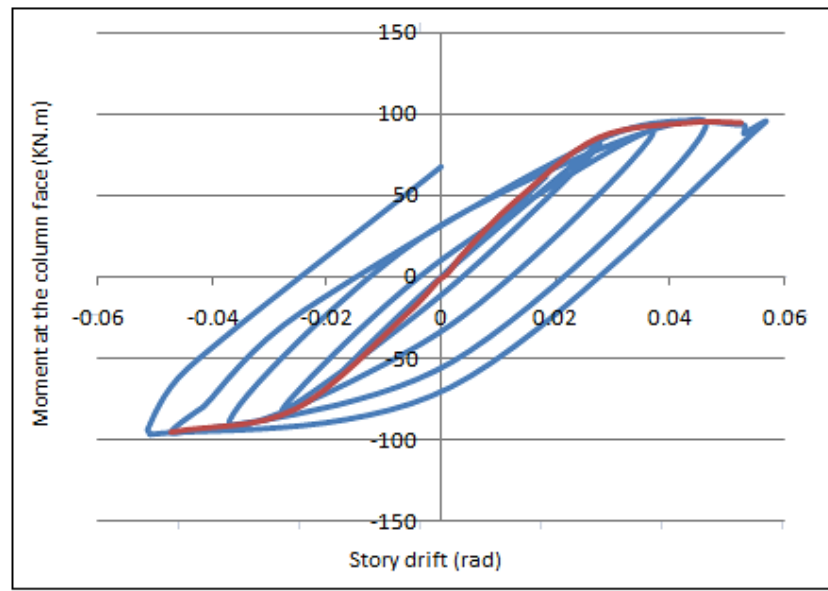

(a) Specimen A200

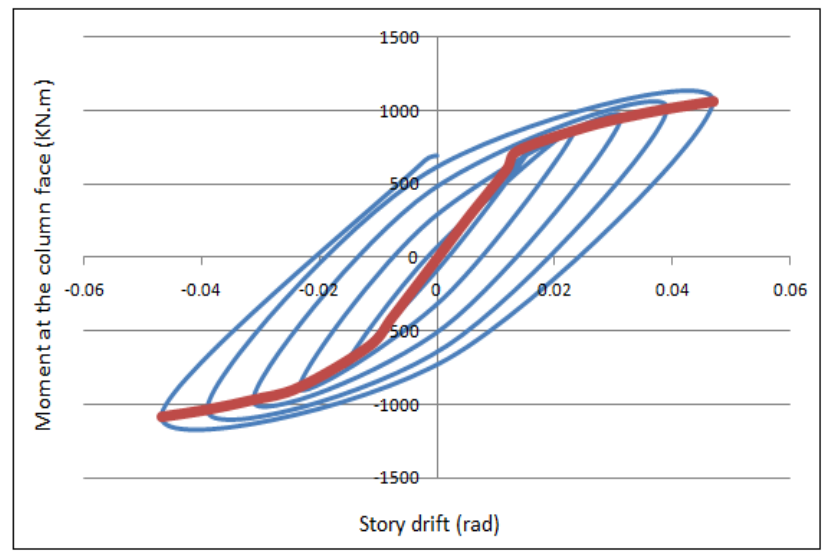

(c) Specimen B350

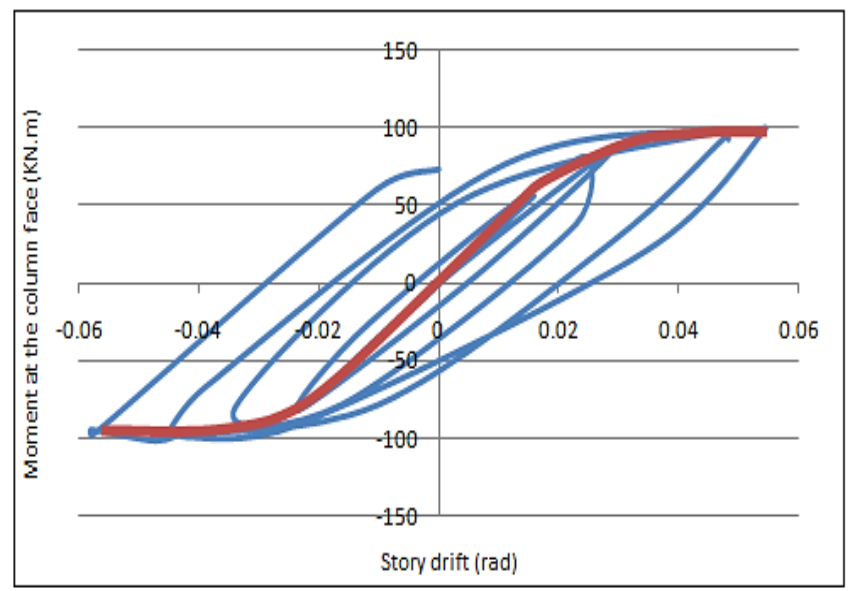

(b) Specimen A200-T

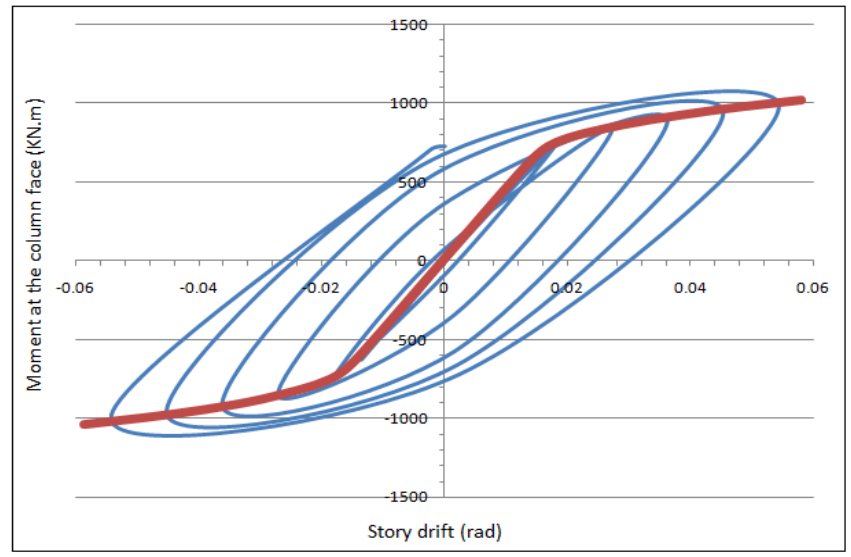

(d) Specimen B350-T 


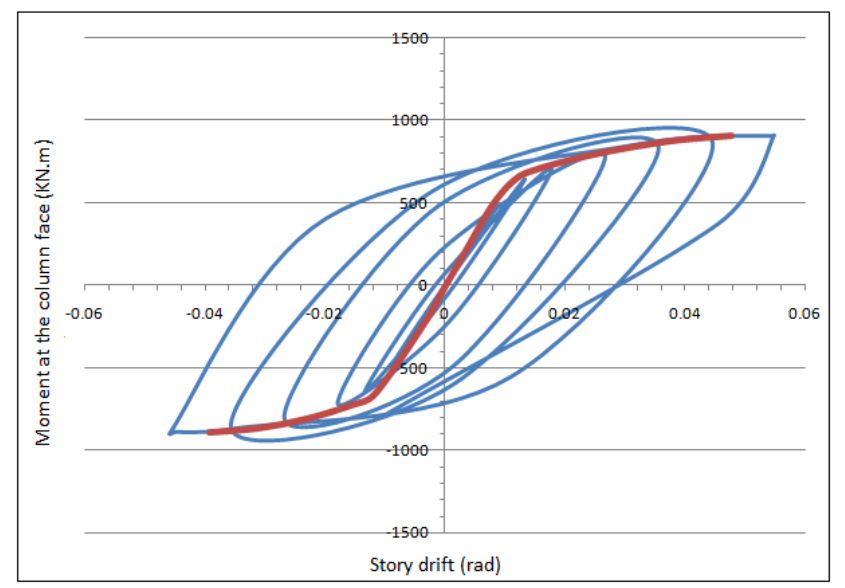

(e) Specimen $\mathbf{C 4 5 0}$

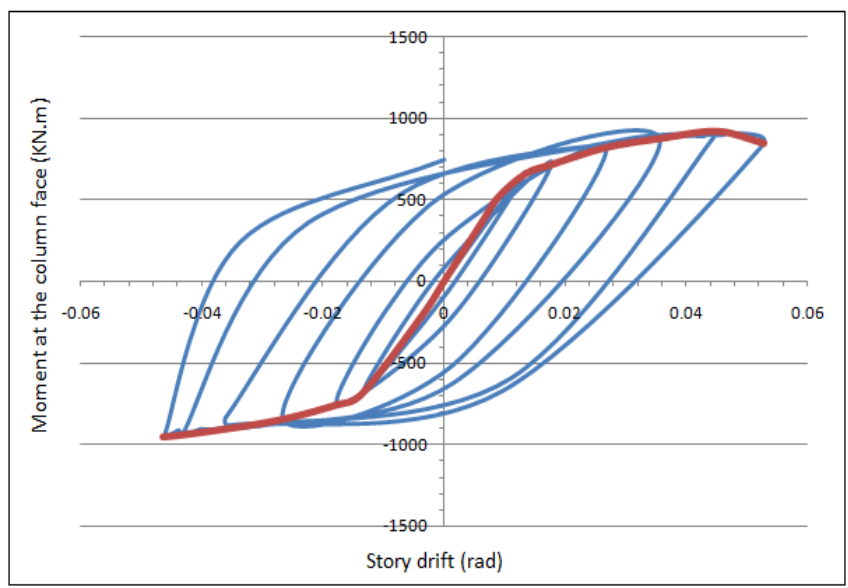

(f) Specimen C450-T

Figure 10. Cyclic moment-rotation and envelope curves for specimens

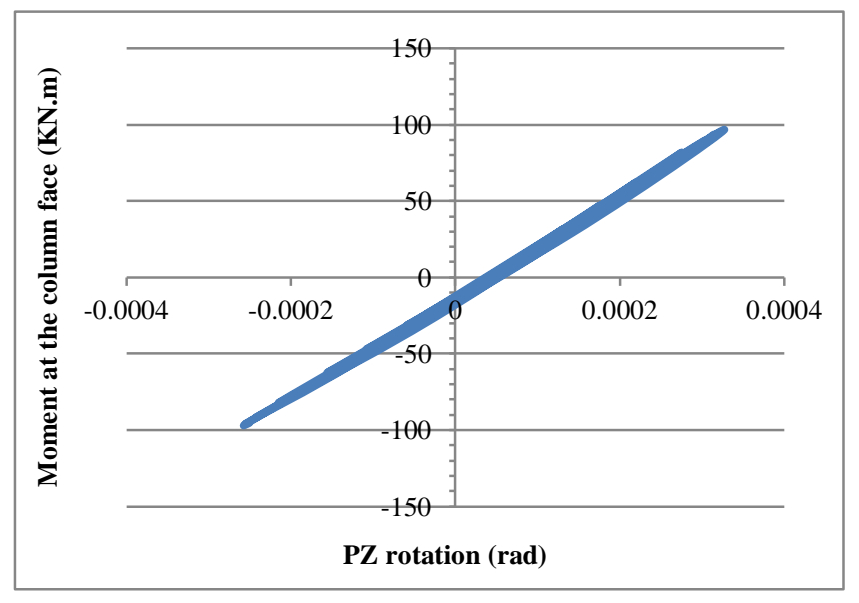

(a) Specimen A200

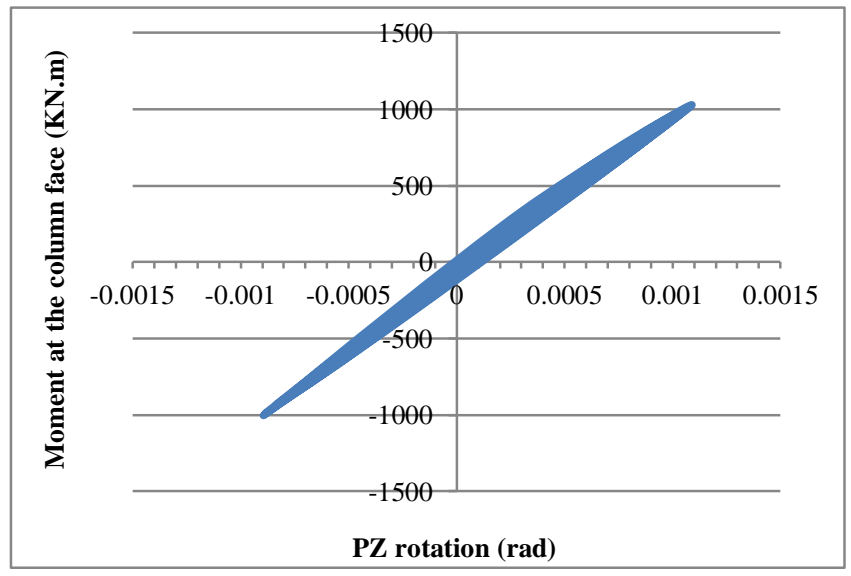

(c) Specimen B350

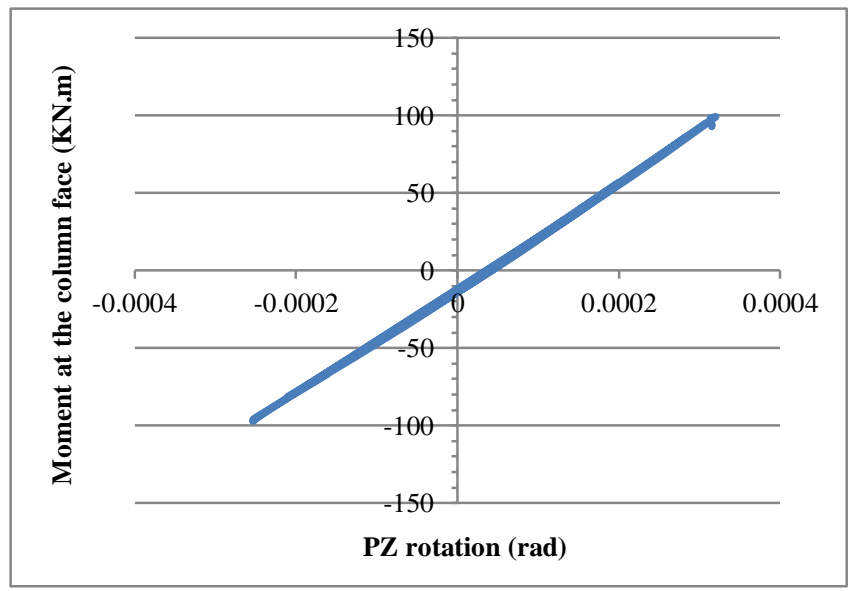

(b) Specimen A200-T

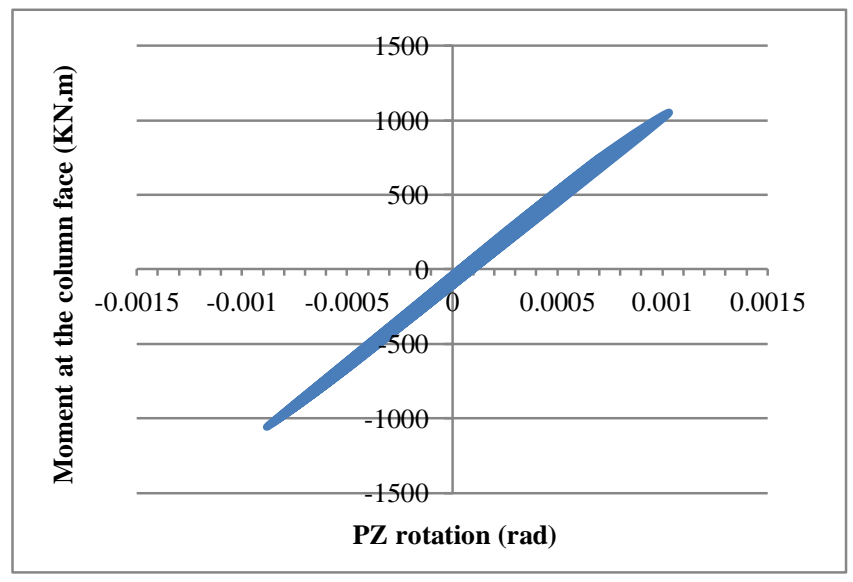

(d) Specimen B350-T 


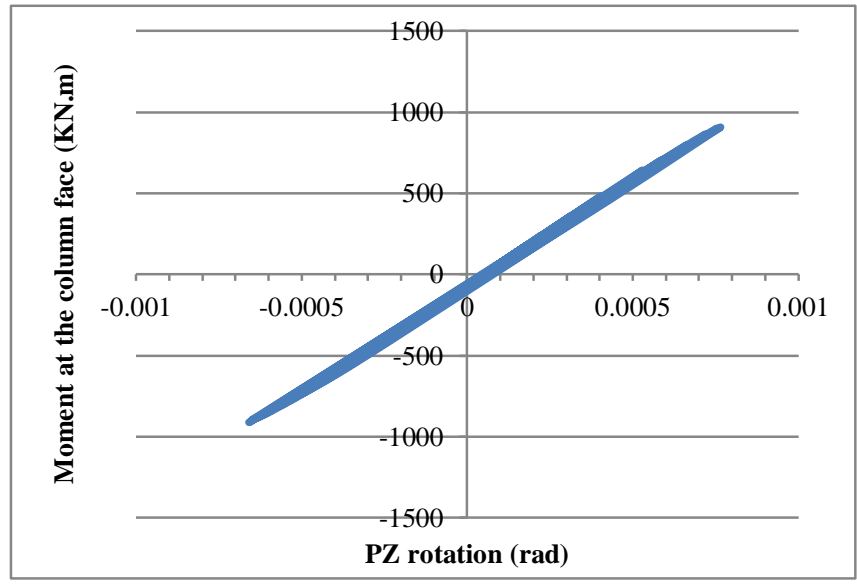

(e) Specimen C450

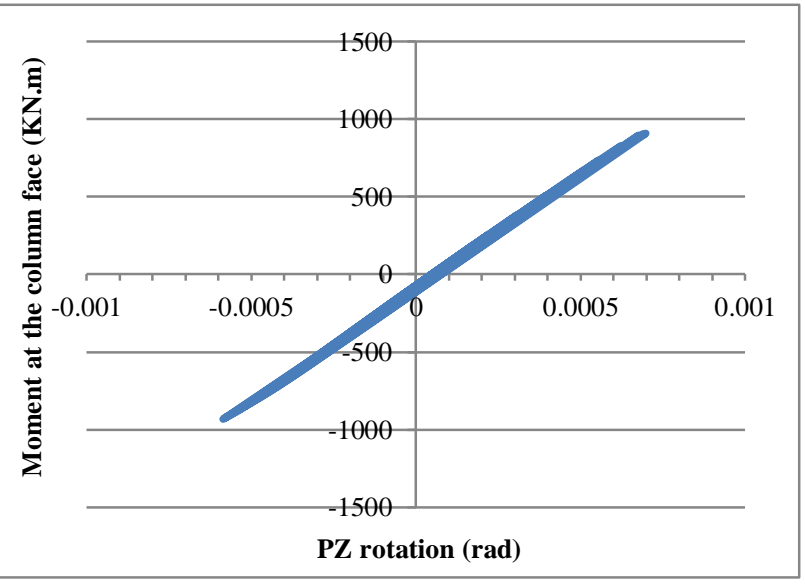

(f) Specimen C450-T

Figure 11. Moment-PZ rotation responses from ABAQUS simulation results of specimens

\section{Conclusion}

In this study we attempted to investigate numerically the cyclic behavior of four-bolt extended end-plate connection connections using finite element analysis. According to the equivalent plastic strain and von-Mises stress distributions, we concluded that the use of end-plate rib stiffener increases equivalent plastic strain and the potential of soft failure in BEEP connections. The increase in the beam height increased the equivalent plastic strain in the plastic hinge location, such that we can say the connections with a larger beam height can cause brittle fracture in the connection area, and rupture in the plastic hinge location. We observed that by increasing the height and the inertia moment of the beam, the strength of the connection increased. Moreover, by comparing moment-rotation hysteretic curves of specimens, we found out that the use of a triangular rib stiffener in BEEP connections with thinner end plate can slightly improve their cyclic behavior; while in connections with thicker end plate, the attachment of rib stiffener showed no considerable effect on cyclic behavior. The use of end-plate rib stiffeners welded to the top and bottom of the beam flanges caused the reduction of connection strength in stiffened connections to be occurred with a delay compared to unstiffened connections. We concluded that the BEEP connections with small end plates and bolts which did not meet the dimensional criteria of the tenth code of Iranian national building regulations, cannot be used in special and intermediate steel moment frames.

In the study, models of the exterior beam-column joint were used. We recommend further study by using interior joint model of beam to column connections, or using different types of bolts for fastening the connection (e.g. shape memory alloy). Also further study is recommended on examining the effect of extended end-plate or column stiffeners on behavior of BEEP connections under cyclic loading. More investigation also can be conducted using other geometries of beam and column.

\section{Notation}

$b_{p} \quad$ End-plate width $\quad M$

$d_{p} \quad$ End-plate depth

$t_{p} \quad$ End-plate thickness

$d_{b} \quad$ Bolts diameter

$t_{s} \quad$ End-plate stiffener thickness

$l_{s} \quad$ End-plate stiffener length

$b_{s} \quad$ End-plate stiffener width

$Q_{\infty}$

$\mathrm{C}_{1}, \mathrm{C}_{2}$

$\mathrm{C}_{3}, \mathrm{C}_{4}$
The maximum change in the size of the yield surface

Kinematic hard parameters of Q345 steel $d_{c}$

$\theta$

$\Delta$

$\sigma \mid 0$

$b$
Bending moment at the column face

Actuator force

Beam length

Column depth

Rotation angle

Lateral displacement

Yield stress at zero equivalent plastic strain

The rate at which the size of the yield surface changes as plastic straining develops 


\section{References}

[1] AISC/ANSI 358-10. "Prequalified Connections for special and intermediate steel moment frames for Seismic Applications." Chicago, US. (2010). https://www.aisc.org/globalassets/aisc/publications/standards/prequalified-connections-for-special-andintermediate-steel-moment-frames-for-seismic-applicatios-aisc-358-16.pdf.

[2] Ismail, R.E.S., Fahmy, A.S., Khalifa, A.M., and Mohamed, Y.M. "Numerical Study on Ultimate Behaviour of Bolted End-Plate Steel Connections." Latin American Journal of Solids and Structures 13(2016): 1-22. https://dx.doi.org/10.1590/1679-78251579.

[3] European Standard (ENV 1993-1-8). "Eurocode 3: Design of steel structure - Part 1-8: Design of joints." European Committee for Standardization (2005). http://www.phd.eng.br/wp-content/uploads/2015/12/en.1993.1.8.2005-1.pdf.

[4] Morrison, M., Quayyum, S. , and Hassan, T. "Performance enhancement of eight bolt extended end-plate moment connections under simulated seismic loading." Engineering Structures 151 (2017) 444-458. https://doi.org/10.1016/j.engstruct.2017.08.040.

[5] Tsai, K., and Popov, EP. "Cyclic behavior of end-plate moment connections." Journal of Structural Engineering, 116 (1990):2917-30. https://doi.org/10.1061/(ASCE)0733-9445(1990)116:11(2917).

[6] Ghobarah, A., Osman, A., and Korol, RM. "Behaviour of extended end-plate connections under cyclic loading." Engineering Structures 12(1990):15-27. https://doi.org/10.1016/0141-0296(90)90034-P.

[7] Korol, RM, Ghobarah, A, and Osman, A. "Extended end-plate connections under cyclic loading: behavior and design.” Journal of Constructional Steel Research 16(1990):253-79. https://doi.org/10.1016/0143-974X(90)90030-K.

[8] Sumner EA. "Unified design of extended end-plate moment connections subject to cyclic loading." Ph.D. thesis. Blacksburg, VA: Virginia Polytechnic Institute and State University, (2003). https://vtechworks.lib.vt.edu/bitstream/handle/10919/28078/etd_Sumner.pdf?sequence=1.

[9]. Shi Y., Shi ,G., and Wang, Y. "Experimental and theoretical analysis of the moment-rotation behavior of stiffened extended end-plate connections.” Journal of Constructional Steel Research 63(2007): 1279-1293. https://doi.org/10.1016/j.jcsr.2006.11.008.

[10] Mohamadi-Shoore, M.R. and Mofid, M. "New modeling for moment-rotation behavior of bolted endplate connections." Scientia Iranica 18(2011): 827-834. https://doi.org/10.1016/j.scient.2011.07.015.

[11] Abidelah, A., Bouchaï, A., Kerdal, D.E. "Experimental and analytical behavior of bolted end-plate connections with or without stiffeners.” Journal of Constructional Steel Research 76 (2012): 13-27. https://doi.org/10.1016/j.jcsr.2012.04.004.

[12] Mashaly, E., El-Heweity, M., Abou-Elfath, H., and Osman, M. "Behavior of four-bolt extended end-plate connection subjected to lateral loading.” Alexandria Engineering Journal 50 (2011):79-90. https://doi.org/10.1016/j.aej.2011.01.011.

[13] Kiamanesh R., Abolmaali A., and Razavi M. "Effect of circular bolt pattern on behavior of extended end-plate connection." Journal of Structural Engineering 139(2012):1833-41. https://doi.org/10.1061/(ASCE)ST.1943-541X.0000765.

[14] Dessouki, A.K., Youssef, A.H. and Ibrahim, M.M. "Behavior of I-beam bolted extended end-plate moment connections." Ain Shams Engineering Journal 4 (2013): 685-699. doi: 10.1016/j.asej.2013.03.004.

[15] Wang, M., Shi YJ., Wang Y.Q., and Shi G. "Numerical study on seismic behaviors of steel frame end-plate connections.".Journal of Constructional Steel Research 90(2013):140-152. https://doi.org/10.1016/j.jcsr.2013.07.033.

[16] Shi YJ., Wang M., and Wang YQ. "Experimental and constitutive model study of structural steel under cyclic loading." Journal of Constructional Steel Research 67(2011):1185-97. https://doi.org/10.1016/j.jcsr.2011.02.011.

[17] American Institute of Steel Construction. "Seismic provision for structural steel building." American Institute of Steel Construction, Chicago, Illinois (2005). https://www.aisc.org/globalassets/aisc/publications/standards/seismic-provisions-forstructural-steel-buildings-ansi-aisc-341-16.pdf.

[18] Department of National Building Codes. "Tenth topic: Design and Implementation of Steel Buildings. 4th edition.” Research Center for Roads, Housing and Urban Development, Tehran, Iran (2013).

[19] Krawinkler, H. "Guidelines for Cyclic Seismic Testing of Components of Steel Structures for Buildings," Report No. ATC-24, Applied Technology Council, Redwood City, CA. (1992). https://www.atcouncil.org/files/ATC-24TOC.pdf.

[20] Castiglioni, C.A. and Drei, A. "Cyclic tests of beam-upright connections in racking systems with a new hybrid procedure." Proceedings of the 7th International Conference on Behaviour of Steel Structures in Seismic Areas (2012): 53-59. DOI:10.1201/b11396-9.

[21] Gholami, M., Tehranizadeh, M., and Deylami, A. "Evaluation of welded flange plate connections between steel beams and box columns." Advanced Steel Construction 9(2013): 59-76. https://doi.org/10.18057/ijasc.2013.9.1.5.

[22] Shi G., Shi YJ., and Wang YQ. "Behaviour of end-plate moment connections under earthquake loading." Engineering Structures 29(2007):703-16. https://doi.org/10.1016/j.engstruct.2006.06.016. 